\title{
REAKTUALISASI PERMAINAN TRADISIONAL UNTUK PENGEMBANGAN KREATIVITAS ANAK
}

\author{
Siti Nur Hayati ${ }^{1}$, Hibana ${ }^{2}$ \\ Fakultas Ilmu Tarbiyah dan Keguruan, Universitas Islam Negeri Sunan Kalijaga Yogyakarta ${ }^{1,2}$ \\ Email: nurhaya912@gmail.com ${ }^{1}$, hibana@uinsuka.ac.id ${ }^{2}$ \\ Hayati, Siti.Nur. (2021). Reaktualisasi Permainan Tradisional Untuk Mengembangkan Kreativitas Anak. \\ Jurnal Pelita PAUD, 5(2), 298-309. \\ doi: https://doi.org/10.33222/pelitapaud.v5i2.1344
}

Diterima:05-06-2021

Disetujui: 21-06-2021

Dipublikasikan: 27-06-2021

\begin{abstract}
Abstrak: Penelitian ini bertujuan untuk membahas permainan tradisional edukatif bagi anak usia dini, yang berisi karakteristik, manfaat, serta jenis pelaksanaan permainan tradisional. Tulisan ini menggunakan metode studi pustaka yang dilakukan dengan menelaah dan/atau mengeksplorasi beberapa buku, jurnal, serta catatan-catatan dan informasi atau data-data lain yang dinilai sesuai dengan kajian atau penelitian. Pada penelitian ini dinyatakan bahwa dengan bermain, salah satunya dengan bermain permainan tradisional dapat memberi sumbangan positif pada anak-anak antara lain berupa: membentuk tubuh yang bugar, sehat, dan tangguh; membentuk toleransi, demokratis, disiplin dan mental sportivitas; membentuk moral jujur, peka, tulus dan tanggap; membentuk kompetensi sosial berdaya saing, berkebangsaan, bekerjasama, dan bersahabat. Dengan permainan tradisional dapat membantu anak-anak meningkatkan perkembangan seluruh aspek yang dimiliki secara terpadu dan menyeluruh untuk menjadi lebih cakap serta terampil. Permainan tradisional masih relevan untuk dilestarikan pada era globalisasi saat ini dan diperlukan dukungan dari berbagai pihak untuk melestarikannya.
\end{abstract}

Kata kunci: permainan tradisional, kreativitas anak.

Abstract: This study aims to discuss traditional educational games for early childhood, which contain characteristics, benefits, and types of traditional games. This paper uses the literature study method which is carried out by examining and/or exploring several books, journals as well as notes and information or other data that are considered in accordance with the study or research. In this study it was stated that by playing, one of them by playing traditional games can make a positive contribution to children, among others, in the form of: form a fit, helaty and tough body; forming tolerance, democracy, discipline and sportsmanship mentality; forming honest, sensitive, sincere and responsive morals; forming social competences that are competitive, national, cooperative and friendly. With traditional games, it can help childrenimprove the development of all aspects they have in an integrated and comprehensive manner to become more capable and skilled. Traditional games are still relevant to be preserved in the current era of globalization and support from various parties is needed to preserve them..

Keywords: traditional game, children's creativity.

http://jurnal.upmk.ac.id/index.php/pelitapaud 


\section{PENDAHULUAN}

Kegiatan bermain bagi anak memiliki kedudukan sangat penting dalam aktivitas sehari-hari. Bermain menggambarkan proses dalam mempersiapkan diri merambah dunia berikutnya, anak memperoleh pengetahuan melalui bermain. Dengan bermain anak akan mengeksplorasi lingkungannya, berhubungan dengan orang yang berusia di atasnya serta kawan sebaya, melatih pertumbuhan fisik, menambah perbendaharaan kata, serta membuat belajar menjadi sangat menyenangkan (Badu, 2011).

Bermain tidak hanya sesuatu yang menyenangkan, tetapi dengan bermain dapat membentuk karakter-karakter dalam diri anak. Menurut Santrock, usia dini merupakan usia bagi anak untuk wajib memenuhi tuntutan pertumbuhan dalam menghadapi persoalan di masa mendatang, sesungguhnya bermain yang dicoba oleh anak dapat melatih konsentrasi untuk mengantarkan anak mencapai kemampuan maksimal (Musyaddad, 2019). Peran orang tua sangat penting dalam memfasilitasi serta menyediakan permainan yang dibutuhkan anak untuk mendukung pertumbuhan dan perkembangannya. Diharapkan dengan bermain, anak akan mengembangkan seluruh aspek perkembangan yang dimiliki. Permainan yang dapat menstimulasi aspek-aspek pertumbuhan dan perkembangan anak antara lain yaitu permainan tradisional. Dharmamulya menyebutkan bahwa permainan tradisional adalah permainan yang bersifat edukatif dan penting untuk menstimulasi aspek-aspek perkembangan pada anak.

Permainan tradisional pada masa dulu dapat dikatan permainan yang cukup populer diantara anak-anak, namun sekarang sudah mulai tergeser keberadaannya dengan permainan modern yang lebih mudah dan praktis. Zaman modern saat ini tak sedikit anak yang mulai melupakan keberadaan permainan tradisional sehingga lebih memilih permainan modern untuk dimainkan. Sejatinya pada permainan tradisional mengandung unsur pembelajaran dan berbagai kecakapan serta keterampilan yang nantinya diperlukan untuk menghadapi tugas sebagai bagian dari masyarakat (Andriani, 2012).

Dewasa ini permainan game online, $P S$, telah menjadi "makanan" harian anak Indonesia, khususnya anak-anak yang berada di daerah perkotaan. Semakin banyaknya tempat sewa $P S$ di kota sampai ke desa, membuat anakanak mulai tertarik untuk memainkan permainan tersebut. Kecenderungan anak untuk memainkan permainan yang dirasa instan membuat keberadaan permainan play station sangat digemari. Semakin majunya teknologi semakin membawa banyak kemudahan bagi anak dalam bermain. Banyak game-game komputer bermunculan dengan berbagai sensasi yang ditawarkan, sehingga anak tertarik dan merasa permainan tersebut sangat mengasyikkan dan kaya fantasi. Memang tidaklah heran, jika keberadaan permainan tradisional sudah mulai ditinggalkan. Keberadaannya telah tergantikan dengan permainan modern dengan segala kemajuan teknologi (Nugrahani, 2012). Permainan menjadi sangat mudah dan praktis, tidak membutuhkan tempat luas dan tidak membutuhkan banyak kawan. Sendirian duduk menghadap monitor komputer pun orang sudah bisa masuk dan tenggelam dalam game yang menyenangkan.

Beberapa faktor yang menjadi penyebab hilangnya permainan tradisional menurut William Tedi (Anggita, 2019) antara lain : a) tidak adanya sarana tempat bermain, b) waktu yang dimiliki anak sangat sempit, mengingat tuntutan zaman yang dibebankan kepada anak sangat kompleks, c) terdesaknya permainan tradisional oleh permainan modern yang sangat praktis, tidak memerlukan tempat yang luas, tidak terbatas waktu dapat dilakukan pagi, siang maupun malam, d) pewarisan budaya dari generasi sebelumnya ke generasi di bawahnya terputus, dikarenakan pemain terdahulu tidak mempunyai kesempatan mensosialisasikan, menulis serta mendokumentasikan sebagai hasil dari kebudayaan.

Permainan tradisional adalah tinggalan budaya dari nenek moyang dan bangsa yang sudah seharusnya dilestarikan keberadaannya. Maka dari itu, telah menjadi suatu keharusan bagi generasi selanjutnya agar tetap melestarikan dan mempertahankan eksistensi permainan tradisional. Tiap-tiap daerah di Nusantara mempunyai permainan tradisional masing-masing dengan kekhasan daerah yang dimiliki. Untuk itu perlu dilakukan sosialisasi permainan tradisional secara berkelanjutan. 
Hal ini bertujuan untuk mencegah musnahnya permainan tradisional di Indonesia (Anggita, 2019).

Berdasarkan uraian di atas, penulis ingin menjabarkan apa itu permainan tradisional edukatif, bagaimana karakteristik permainan tradisional, dilihat dari aspek kebudayaan apakah masih sesuai jika permainan tradisional tetap dilestarikan pada era globalisasi saat ini, apabila masih sesuai bagaimana cara yang dapat dilakukan agar permainan tradisional tetap lestari, serta apa manfaat dilestarikannya permainan tradisional.

\section{METODE PENELITIAN}

Metode yang digunakan bersifat literatur dan termasuk pada jenis penelitian pendekatan kepustakaan (library reseach). Pengumpulan data dalam penelitian dilakukan dengan menelaah dan/atau mengeksplorasi beberapa buku, jurnal, serta dokumen-dokumen serta sumber data atau informasi lain yang relevan dengan topik penelitian. Sumber-sumber kepustakaan dalam penelitian ini diperoleh dari buku, jurnal, dan hasil-hasil penelitian (skripsi, tesis, disertasi). Sehingga dalam penelitian ini meliputi proses umum. Seperti mengidentifikasi teori secara sistematis, penemuan pustaka, dan analisis dokumen yang memuat informasi yang berkaitan dengan topik penelitian.

\section{Prosedur Penelitian}

Berdasar pemaparan Zed (2008) dalam (Azizah, 2017) langkah-langkah pada library research diantaranya pertama mempunyai gagasan umum tentang pokok riset, kedua mengumpulkan informasi untuk menunjang pembahasan, ketiga menguatkan inti penelitian, keempat mengelompokkan bahan bacaan yang telah ditemukan, kemudian mencatat bahan penelitian yang telah dibaca, selanjutnya menambah bacaan, dan yang terkahir menulis bahan bacaan yang telah dikelompokkan

\section{Sumber Data}

Pada penelitian ini sumber data berasal dari jurnal maupun buku yang berkaitan dengan penelitian yang dilakukan, dimana sumber data berasal dari 23 jurnal yang memiliki kesesuain dengan fokus kajian.

\section{Instrument dan Teknik Mengumpulkan Data}

Penelitian ini menggunakan instrument berupa data check-list untuk mengelompokkkan bahan penelitian, peta penulisan serta format catatan penelitian. Sedangkan teknik mengumpulkan data menggunakan pendokumentasian yaitu dengan mencari data berupa buku, jurnal, catatan, buku dan lainlain.

\section{Teknik Analisis Data}

Penelitian ini menggunakan teknik analisi data berupa metode analisis isi dimana metode ini digunakan sebagai inferensi yang shahih yang dapat diteliti ulang berdasar konteksnya (Kripendoff dalam Azizah, 2017). Agar tetap terjaganya keabadian proses pengkajian serta mencegah terjadinya salah persepsi maka diperlukan pengecekan ulang dan membaca kembali bahan-bahan kepustakaan serta menyimak masukan dari pembimbing (Sutanto dalam Azizah, 2017).

\section{HASIL PENELITIAN DAN PEMBAHASAN}

Reaktualisasi pada konteksi ini merupakan suatu gagasan atau konsep yang memiliki upaya untuk menghadirkan kembali nilai-nilai lokal dan spirit dalam permainan tradisional. Dalam KBBI (Kamus Besar Bahasa Indonesia) kata reaktualisasi merupakan perbuatan, proses mengaktualisasi kembali (Nugrahani, 2012). Maksud dari reaktualisasi sendiri adalah untuk memperbaharui dan penyegaran kembali nilai-nilai yang ada di masyarakat yang mana dalam hal ini adalah permainan tradisional.

\section{Definisi Permainan Tradisional Edukatif}

Banyak yang mengalami kesulitan dalam mendefinisikan istilah bermain bahkan menurut Hurlock (Badu, 2011) memberikan definisi bermain adalah suatu kegiatan yang dilaksanakan semata-mata hanya demi kegembiraan dan kesenangan dengan mengesampingkan hasilnya. Selian itu ahli lain Huizinga (Badu, 2011) mengartikan bermain sebagai kegiatan suka rela, dan pelaksanaannya dibatasi oleh ruang dan waktu, sesuai aturan yang disepakati dengan suka rela namun bersifat mengikat, diri sendiri sebagai tujuan disertai dengan rasa tenang dan senang. Bagi anak usia dini bermain mempunyai manfaat yang sangat besar bagi pertumbuhan dan perkembangannya. Hal ini 
termuat pada kurikulum yang menjadikan sebuah kebijakan bahwasanya bermain adalah jalan terbaik dalam mengasah kemampuan anak prasekolah. Bermain adalah cara alami anak untuk menemukan dirinya, orang lain dan lingkungannya.

Permainan tradisional edukatif merupakan unsur kebudayaan bangsa yang terdapat di seluruh pelosok Nusantara. Permainan tradisional merupakan kegiatan yang dapat membuat hati anak senang dengan menggunakan alat-alat sederhana yang cocok dengan kondisi dan merupakan hasil penggalian budaya yang ada di suatu tempat secara turun temurun berasal dari nenek moyang. Penyebutan lain dari permainan tradisional adalah permainan rakyat, dalam permainan tradisional terdapat nilai-nilai pendidikan dan budaya dan juga dapat membuat pemain bersenang hati (Badu, 2011).

Permainan tradisional Indonesia banyak digunakan sebagai ajang untuk mempersiapkan jenjang kehidupan selanjutnya, dan hanya sedikit yang menitik beratkan sebagai media mencari hiburan atau ketenangan. Hal yang ada dalam permainan tradisional antara lain, pedoman hidup, proses, serta fungsi pada permainan tradisional adalah perantara tepat untuk belajar. Pendapat Rudi co Rens bahwa melalui permainan tradisional anak akan bermain dengan riang gembira tanpa paksaan, dan setelah selesai bermain tanpa disadari ternyata ada bekal yang di dapat untuk kehidupan (Badu, 2011). Jika kesempatan yang diberikan kepada anak untuk bermain semakin banyak, maka akan bertambahlah pengalaman yang dimiliki. Bermain sangat diperlukan anak untuk pengembangan diri (Hasanah, 2016).

Selain itu menurut Muhammad Zaini Alif (Badu, 2011) hal-hal yang didapat dari permainan tradisional yakni permainan tradisional dapat mengajarkan anak untuk melestarikan alam sekitar, cinta kepada Tuhan, dan menghormati sesama. Hal lain dikemukakan oleh Ni Nyoman Seriati (Badu, 2011) bahwa permainan tradisional lambat laun mengalami penuruan eksistensi, permainan tradisional mulai ditinggalkan dan jarang terlihat dimainkan anak-anak baik di kota maupun di desa. Padahal menurut Ni Nyoman Seriati, permainan tradisional banyak mengandung nilai moral, kebudayaan bahkan dapat mengembangkan keterampilan misalnya disiplin, jujur, bekerjasama, musyawarah karena adanya peraturan yang wajib ditaati bagi setiap pemain.

Hal senada juga diungkapkan oleh Edy Waspada (Hasanah, 2016) bahwa permainan tradisional hanya memerlukan bahan serta alat yang sesuai dengan budaya suatu masyarakat. Nama lain permainan tradisional adalah permainan rakyat, permainan tradisional adalah kegiatan rekreatif dengan tujuan mencari hiburan, selain itu permainan tradisional juga bertujuan untuk memelihara hubungan sosial antar masyarakat. Karakter yang terdapat dalam permainan tradisional dapat membentuk karakter positif dalam diri anak (Rahadian, 2020).

Berdasarkan beberapa pengertian di atas maka dapat disimpulkan bahwa permainan tradisional edukatif merupakan permainan yang telah ada jaman dulu dan diwariskan secara turun temurun. Permainan tradisional mengandung nilai pembelajaran dan kebudayaan dan juga dapat membuat senang hati para pemainnya.

\section{Sejarah Permainan Tradisional}

Kata "permainan" berasal dari kata dasar "main" yang artinya kegiatan yang dilakukan untuk bersenang-senang. Dari pengertian di atas maka permainan adalah untuk kegiatan yang menimbulkan atau menciptakan kegembiraan bagi pemainnya. Ki Hajar Dewantara dalam bukunya yang berjudul "Tentang Frobel dan Metodenya", menganjurkan syarat-syarat yang diperlukan dalam suatu permainan anak yang bertujuan untuk pendidikan antara lain permainan harus menggembirakan, memberikan kebebasan anak berfantasi, berimajinasi agar kreativitas anak terangsang, serta permainan hendaknya mempunyai nilai-nilai yang mengarah pada kedisiplinan, kebersamaa, ketertiban, serta sportivitas (Nugrahani, 2012).

Menurut Kamus Besar Bahas Indonesia (KBBI) "tradisional" berasal dari kata dasar "tradisi" yang memiliki arti kebiasaan yang telah terjadi secara turun temurun dan masih dilakukan hingga saat ini. Sedangkan "tradisional" merupakan sikap dan cara berpikir serta bertingkah laku sesuai dengan adat istiadat kebiasaan turun temurun. Maka dapat disimpulkan bahwa permainan yang 
telah ada sejak zaman dahulu dan diturunkan secara turun temurun dari satu generasi ke generasi selanjutnya disebut dengan permainan tradisional. Permainan tradisional memuat gambaran tentang kehidupan seharihari dan terdapat nilai positif guna meningkatkan kesehatan mental, jasmani serta rohani. Tempat dimana kebudayaan itu berasal sangat mempengaruhi permainan tradisional, hal tersebut dapat berupa penambahan, pengurangan, atau bahkan pergantian dimana terjadi penyesuaian dengan daerah asal. Secara keseluruhan terdapat perbedaan dan kesamaan antara permainan satu dengan permainan yang lain dari tiap-tiap daerah di Indonesia hanya penamaannya saja yang berbeda (Nugrahani, 2012). Terjadinya interaksi secara fisik, emosi dan mental setiap anggota masyarakat saat berkumpul melakukan permainan tradisional (Hapidin, 2016).

Tidak diketahui secara pasti kapan dan dimana asal mula permainan tradisional ini muncul dan berkembang. Berdasarkan cerita, peninggalan-peninggalan jenis permainan dapat diketahui terjadi saat akhir abad 19 hingga awal abad 20. Dapat ditemukan mengenai cara, aturan, jenis, macam, serta lagu-lagu yang dinyanyikan.

\section{Karakteristik Permainan Tradisional}

Karakteristik yang dimiliki permainan tradisional yang berbeda dengan permainan modern yaitu pertama, penggunaan bahasa daerah dalam permainan tradisional menunjukkan ciri kebudayaan setempat (Andriani, 2012). Bahasa daerah yang dipakai dalam permainan tradisional tidak bias diganti karena dapat mengurangi makna, menghilangkan nilai luhur serta moral yang terdapat pada permainan tersebut (Anggita, 2019). Kedua, sejak kecil anak sudah belajar memainkan permainan tradisional. Permainan mudah diserap dengan cepat saat masih anakanak dan mengendap dalam alam bawah sadarnya. Yang terdapat dalam alam bawah sadar nantinya akan tertanam kuat dan memunculkan kenangan kembali ke masa kecil (Andriani, 2012).

Ketiga, permainan tradisional sering memakai dan mendayagunakan barang-barang yang ada di lingkungan tanpa membelinya. Keempat, diperlukan kreativitas dan imajinasi yang tinggi bagi pemain untuk mengartikan, merepresentasikan, serta mendayagunakan benda yang dipakai saat bermain sesuai dengan yang dibutuhkan. Tanpa imajinasi dan kreativitas tinggi, tulang daun pisang mustahil akan disulap menjadi pistol mainan dan dimanfaatkan sebagai permainan kuda-kuda mainan (Anggita, 2019).

Kelima, dari segi jumlah pemain, dalam permainan tradisional melibatkan banyak pemain atau berorientasi komunal. Tidak heran jika melihat permainan tradisional memiliki jumlah pemain yang banyak karena dalam permainan selalu mendahulukan kegembiraan bersama. Maksud lain dari banyaknya jumlah pemain dalam permainan tradisional adalah untuk meningkatkan interaksi setiap pemain dengan pemain yang lainnya. Seperti contoh permainan petak umpet, boy-boyan, dan congklak tidak bisa dimainkan sendiri. Namun demikian, ada juga beberapa permainan tradisional yang dapat dimainkan sendiri (Andriani, 2012).

Diperlukan adanya pelestarian dari lingkungan. Permainan tradisional tidak hanya dapat menghilangkan stress pada anak atau sekedar membantu anak lebih fokus dalam belajar, tetapi dengan permainan tradisional juga mengajarkan nilai tanggung jawab, lapang dada, kejujuran, kebersamaan, dan taat terhadap aturan. Hal tersebut tentu dapat dirasakan jika pemain menghayati, menikmati, serta mengerti arti permainan yang dimainkan (Anggita, 2019).

\section{Jenis dan Pelaksanaan Permainan Tradisional}

Indonesia memiliki permainan tradisional yang sangatlah beragam dan banyak jumlahnya, tapi pada kesempatan kali ini penulis akan mencontohnya beberapa permainan tradisional yang ada di Nusantara.

\section{Engklek}

Cara bermain permainan engklek adalah dengan melompati sebuah garis menggunakan satu kaki. Engklek menurut Dharmamulya merupakan permainan melompati bidang datar yang telah digambar di atas tanah disertai dengan lempar gacu. Nama lain dari permainan engklek adalah sunda manda yang kemudian dipercayai berasal dari kata "Zondag Maandag" merupakan kata serapan dari bahasa Belanda yang artinya meloncati garis dengan satu kaki. Sedangkan menurut Montolalu (Apriani, 2013) engklek adalah permainan tradisional yang cara memainkannya yaitu dengan melompati 
bidang datar yang di atasnya berupa gambar kotak-kotak, menggunakan satu kaki melompat dari kotak satu ke kotak selanjutnya. Permainan engklek dapat dilakukan oleh 2 anak sampai 5 anak

Menurut Mulyani tahapan bermain engklek antara lain: 1) menggambar pola engklek, memerlukan lahan seluas kurang lebih 3-4 $\mathrm{m}^{2}$. Untuk membuat kotak, anak dapat menggunakan kapur, 2) menentukan pemain pertama, biasanya sebelumnya dilakukan gambreng untuk menentukan yang pertama dapat memulai permainan dan seterusnya, 3) step pertama pemain memulai permainan engklek dengan melemparkan gacu (biasanya dari pecahan genting) menuju kotak pertama, jika gacu tidak mendarat di kotak pertama tetapi mendarat di kotak lain maka permain dinyatakan mati kemudian digantikan oleh pemain selanjutnya. Kotak yang di atasnya terdapat gacu maka tidak diperbolehkan ditempati atau diinjak oleh pemain lain dan pemain lain harus melompat ke kotak selanjutnya. Kemudian pemain melempar gacu ke kotak kedua sampai kotak terakhir dengan aturan yang sama. Satu putaran permainan terhitung jika pemain telah sampai pada gunung (kotak paling atas), membelakangi kotak untuk mengambil gacu, tidak diperbolehkan membuka mata (terpejam) saat mengambil gacu dan tidak boleh menyentuh garis, jika garis tersentuh oleh pemain saat mengambil gacu maka pemain mati (gugur). Jika semua sudah selesai dilalui maka saatnya untuk mendapat lahan (sawah) caranya yaitu dengan menjagling gacu bolak balik sebanyak 5 kali dengan menggunakan telapak tangan dan tidak boleh terjatuh. Pemenang dalam permainan ini adalah pemain dengan sawah terbanyak (Trisnawaty, 2017).

\section{Congklak}

Permainan congklak menurut (Munawaroh, 2018) merupakan permainan tradisional yang berhubungan dengan berhitung dan memakai benda sebagai media bermainnya serta memiliki aturan yang telah disepakati untuk dipatuhi selama berlangsungnya permainan. Yulianti (Niyati \& Kurniah, 2016) berpendapat bahwasanya permainan tradisional congklak membantu anak untuk berlatih menghitung. Selain itu dipertegas lagi dengan pernyataan dari Achroni (Niyati \&
Kurniah, 2016) bahwa permainan tradisional congklak berasal dari Bengkulu yang dapat dimainkan oleh dua anak yang duduk saling berhadapan, dan posisi congklak berada di depan anak-anak.

Istilah congklak di daerah Jawa disebut dengan dakon. Sedangkan untuk penyebutan dengan bahasa Indonesia adalah congklak. Menurut Ovieta asal kata dakon adalah daku yang memiliki arti pengakuan atas milik. Papan congklak dapat berupa papan dengan lumbung dengan panjang dan lebar $50 \mathrm{~cm}$ dan $20 \mathrm{~cm}$, terdapat pula lubang di bagian kanan dan kiri yang berfungsi sebagai tempat menyimpan biji milik pemain. Jumlah lumbung pada papan congklak bervariasi, ada yang 14, 18 bahkan ada yang 22. Biji congklak biasanya berupa sejenis cangkang kerang atau biji-bijian dari tumbuhan. Perkembangan kognitif anak dapat terasah saat bermain congklak, anak belajar berhitung menyebut jumlah biji-bijian yang ada dalam masing-masing lubang. Kemudian selain berhitung, anak juga belajar mengatur strategi karena anak perlu pintar membagi jumlah bijibijian dalam genggaman supaya tidak masuk ke dalam lubang milik lawan (Munawaroh, 2018).

\section{Lompat tali}

Lompat tali merupakan salah satu permainan yang sangat digemari anak. Permainan lompat tali terkenal pada tahun 80 -an di kalangan anak-anak. Pemain lompat tali dapat berjumlah 3 sampai 10 anak dan dapat dimainkan bersama-sama. Permainan ini termasuk ke dalam permainan yang sangat sederhan karena pemain cukup melompati tali dengan ketinggian yang telah ditentukan. Menurut Puspitawati alat bantu berupa tali yang dipakai dalam permainan ini berasal dari susunan gelang karet yang dianyam rapi. Selain itu menurut Ajun permainan lompat tali dipegang oleh dua orang dan membutuhkan seutas tali atau karet, dan kelompok yang satunya menjadi pemain (Widya et al., 2018). Pendapat lain juga diungkapkan oleh Hasan (SPD \& Lailiyyah, 2018) bahwa bentuk permainan lompat tali dimulai dari dasar seperti anak mulai melompat dengan satu kaki pada tali yang digerak-gerakkan seperti ular di tanah dan meningkat dengan melompati tali dalam posisi ketinggian lebih kurang $15 \mathrm{~cm}$, begitu seterusnya sehingga tali dinaikkan 
sampai ukuran ketinggian sepaha anak. Saat pemain dapat melompati tali dengan lancar, maka pemain tersebut dapat bermain terus menerus tanpa henti. Tetapi jika gagal melompati tali, maka pemain harus diantikan pemain lawan untuk memegang tali sampai pemain lawan gagal melompat.

Cara memainkan permainan lompat tali diperlukan dua anak untuk memagangi karet di sisi kanan dan kiri. Selanjutnya, pemain lawan melompati karet dengan ketinggian yang sudah disepakati yaitu mulai dari mata kaki, naik ke lutut, kemudian paha, sampai ke pinggang. Setelah itu dada, kemudian dagu, naik ke telinga, sampai ubun-ubun, tangan dinaikkan sampai atas tanpa jinjit, terakhir jinjit setinggi-tingginya. Pemain lawan harus menyelesaikan tahapan ketinggian yang ada tanpa menggunakan bantuan alat apapun. Permainan ini lebih popular dimainkan oleh anak perempuan, tetapi tak jarang anak lakilaki juga bermain lompat tali. Diperlukan keterampilan khusus untuk memainkan permainan lompat tali karena pemain diharuskan melompati tali setinggi 2 sampai 4 meter tanpa alat bantu apapun (Mu'mala, Abad \& Nadlifah, 2019).

\section{Gobak sodor}

Penyebutan permainan gobak sodor berbedabeda sesuai dengan dari mana permainan ini berasal. Nama gobak sodor lazim digunakan di daerah Jawa Tengah, arti dari gobak sodor sendiri adalah benda yang panjang. Menurut Ariyanti (Ekayati, 2015) permainan gobak sodor memerlukan arena yang berbentuk bujur sangkar yang ditulis di atas tanah dengan menggunakan kapur, diperlukan dua tim untuk memainkan permainan ini yaitu tim lawan dan tim penjaga. Anggota tim pemain memiliki misi untuk mencapai garis belakang secara bergantian. Pergantian pemain terjadi saat salah satu anggota pemain tersentuh oleh anggota tim lawan. Skor 1 didapat saat tim pemain mampu melewati area lapangan gobak sodor tanpa tersentuh.

Permainan gobak sodor memiliki kelebihan dan kekurangan, adapun kelebihannya yaitu murah dalam biaya. Permainan gobak sodor hanya memerlukan pecahan genting, batu bata atau kapur tulis untuk membuat gambar pembatas daerah permainan. Sedangkan kekurangannya yaitu, permainan gobak sodor memerlukan lahan yang luas dalam permainannya (Erdiana, 2016). Penyebutan lain dari permainan gobak sodor di berbagai daerah yaitu banteng sodor, cak bur, hadang atau galasin. Ruswan (Iswantiningtyas \& Wijaya, 2015) mengungkapkan bahwa manfaat yang di dapat saat bermain gobak sodor adalah fisik semakin kuat, terjalin hubungan sosial antar pemain, meningkatkan kreativitas dan membentuk kepribadian. Dalam bermain gobak sodor dapat juga melatih kelincahan, ketangkasan, dan keterampilan. Anak akan bebas bergerak memainkan lawan demi mencapai tujuan akhir yaitu kotak belakang tanpa tersentuh, dan tim penjaga hanya dapat bergerak mengikuti arah garis guna menyentuh tubuh pemain (Sudarto, 2018).

\section{Egrang}

Permainan tradisional egrang adalah permainan yang cukup dikenal masyarakat. Di Sumatera Barat permainan egrang lebih terkenal dengan nama tengkak-tengkak (pincang). Asal mula permainan egrang ini adalah dari daerah Lampung, arti egrang adalah permainan yang terbuat dari bambu bulat yang menyerupai terompah pancung. Bahan pembuat permainan egrang adalah bambu dengan panjang sekitar 2,5 meter. Menurut Lusiana (Bakhtiar, 2018) egrang terbuat dari dua batang bambu dengan panjang 2 meter pada masing-masing bambu. Setelah itu sekitar $50 \mathrm{~cm}$ dari bagian bawah bambu diberi lubang untuk memasukkan bambu dengan ukuran 20-30 $\mathrm{cm}$ yang memiliki fungsi sebagai pijakan. Untuk memainkan egrang, pemain berlomba berjalan berkeliling di atas egrang, yang lebih dulu tiba maka itulah yang memenangkan permainan. Manfaat dari permainan egrang sendiri antara lain: 1) melatih otot kaki dan tangan, 2) melatih kelentukan, 3) meningkatkan koordinasi mata dan tangan, dan 4) meningkatkan keseimbangan tubuh (Anggita, 2019).

Untuk anak usia dini, permainan egrang bambu tentu tidak sesuai dengan tingkat perkembangannya. Oleh karena itu ada juga permaian egrang yang lain yaitu egrang batok kelapa. Permainan egrang batok kelapa ini menggunakan alat batok kelapa dan tali yang dapat diperoleh dari lingkungan sekitar. Cara bermainnya adalah anak naik di atas batok kelapa yang sudah terpasang tali kemudian berjalan dengan menjaga keseimbangan (Khusnul laely, 2015). 


\section{Manfaat Permainan Tradisional}

Secara umum, rangsangan dari segala jenis permainan dapat membentuk jaringan otak untuk membantu cara berpikir, berkepribadian dan berperilaku pada seseorang. Aturan yang telah disepakati dalam permainan tradisional harus dipatuhi setiap pemain, diperlukan juga sikap sportif dalam melaksanakan permainan tradisional. Bermain bagi anak-anak akan membantu anak dalam mengerti, mempraktekkan, serta mengembangkan rasa, intelektual, sosial mereka dengan kesenangan sehingga proses kegiatan bermain dapat memberikan hasil bagi proses belajar anakanak (Andriani, 2012).

Manfaat permainan tradisional menurut Mayke S. Tedjasaputra adalah menjadi sarana anak agar dapat mempelajarai budaya lokal, peran sosial, serta berkomunikasi dengan teman-teman untuk mengungkapkan ide atau gagasan, perasaan serta mampu memahami yang ingin disampaikan oleh orang lain, sehingga komunikasi bisa terjalin. Hal senada juga dikemukakan oleh Sukirman bahwa permainan tradisional memiliki manfaat sebagai cara membiasakan anak berinteraksi dengan individu atau kelompok serta menciptakan kesenangan, berteman, bebas, tanggung jawab, demokrasi, patuh dan saling membantu yang merupakan nilai-nilai baik yang dapat bermanfaat bagi kehidupannya (Andriani, 2012).

Permainan tradisional memilki nilai yang positif untuk dikembangkan. Nilai positif yang terdapat dalam permainan tradisional terlihat pada bahasa yang digunakan, aktivitas baik fisik maupun psikis, serta nyanyian yang terdapat dalam permainan tradisional. Unsur kesenangan saat memainkan permainan tradisional membantu anak dalam belajar berdasarkan keinginan sendiri dengan tanpa paksaan dari siapapun. Anak-anak dengan kecenderungan ambivalent dengan peraturan orangtua atau orang dewasa membutuhkan pendekatan dengan menggunakan permainan tradisional, unsur kesenangan itulah yang menjadikan anak mau melakukan suatu kegiatan tanpa paksaan atau dengan sukarela (Badu, 2011).

Selain itu, menurut Rahmawati (Anggita, 2019) manfaat permainan tradisional antara lain 1) dapat meningkatkan kretivitas anak dalam belajar atau mengembangkan ide, 2) empati dan kecerdasan sosial anak akan semakin meningkat, 3) mengasah kecerdasan bermusik, kinestetik, bahasa dan natural, 4) mengembangkan kecerdasan interpersonal seperti contoh menyepakati aturan main, berkonflik, dan berdamai, 5) melatih koordinasi otak kiri dan otak kanan, 6) mengembangkan nilai EQ, 7) melatih motorik anak, menumbuhkan fisik yang kuat, serta mencegah obesitas, dan 8) belajar mematuhi peraturan karena termotivasi oleh pengakuan sikap sportif dari anak lain. Hal lain juga disampaikan oleh Sururiyah tentang manfaat permainan tradisional yaitu untuk melatih kerjasama, melatih interaksi sosial, untuk melatih emosi anak, dan melatih anak menjadi kreatif.

Manfaat dari permainan tradisional yang lain menurut (Hasanah, 2016) dari segi perkembangan aspek fisik motorik adalah anak memperoleh system keseimbangan ketika berayun atau melompat, selain itu permainan tradisional melibatkan koordinasi mata dan tangan sehingga rasa percaya diri anak akan meningkat. Kemudian dari segi aspek perkembangan kognitif, permainan tradisional membuat anak-anak terlatih membangun pikiran abstraknya dengan membuat aturan dalam permainan, sehingga timbullah ide-ide kreatif anak. Perkembangan aspek bahasa anak juga meningkat saat anak memakai bahasa yang efektif dalam berkomunikasi dengan orang di sekitar baik sekedar berkomunikasi biasa atau menyatakan pikiran. Dengan bermain akan menambah perbendaharaan kata serta belajar menggunakan bahasa yang baik dan benar. Dari segi pertumbuhan aspek sosial emosional, permainan tradisional memiliki manfaat dapat meningkatkan interaksi anak dengan orang di sekitarnya, apakah itu yang lebih dewasa, sebaya, atau yang lebih muda. Masa inilah anak-anak memiliki kesempatan untuk mengerti aturan serta mengaplikasikannya. Anak akan belajar berunding, mengatur emosi saat bermaian, dan hidup berdampingan dengan orang lain.

\section{Permainan Tradisional sebagai Media Pembelajaran}

Permainan tradisional daerah sangat berpotensi digunakan sebagai media dalam pembelajaran. Beragamnya permainan 
tradisional yang mengandung nilai-nilai kejujuran, kegigihan, sportivitas, dan gotong royong perlu digali dan dikembangkan. Dalam mengembangkan sikap kerjasama dan kompetensi dapat dilakukan dengan permainan gobag sodor, untuk meningkatkan keterampilan kognitif dapat menggunakan permainan dakonan sebagai media pembelajarannya. Perkembangan fisik motorik anak dapat dikembangkan dengan permainan engklek, selain itu ada juga permainan pasaran atau jual beli yang bermanfaat sebagi sarana pembelajaran dengan model tematik. Permainan ini mencakup berbagai aspek perkembangan anak seperti kognitif (berhitung), bahasa (percakapan saat jual beli), sosial (interaksi saat kegiatan jual dan beli), nilai moral agama (jujur), motorik (pergerakan yang dilakukan anak saat kegiatan jual dan beli), seni (keterampilan membungkus dan melipat benda). Penggunan permainan pasaran untuk pembelajaran bagi anak dapat dilakukan dengan cara yang menyenangkan dan dapat memanfaatkan barang-barang yang berada di sekitar lingkungan. Contohnya sebagai pengganti gula memakai pasir, sebagai pengganti beras menggunakan kerikil kecil, sebagai pengganti minyak goreng menggunakan air, dan masih banyak lagi pemanfaatan barang-barang disekitar yang dapat digunakan. Dengan permainan tradisional pasaran ini anak akan dilatih untuk bersabar dalam menunggu giliran jual beli, dan bersosialisasi dengan melakukan tawar menawar barang, mengenalkan dan mencintai permainan tradisional harus ditanamkan sejak dini agar permainan tradisional tidak hilang tergerus jaman (Anggita, 2019).

\section{Permainan Tradisional sebagai Media Pengembangan Otak Kanan}

Kegiatan bermain pada anak dapat memberikan kesempatan anak untuk menguji sejauh mana kemampuan yang dimiliki dengan teman sebaya serta untuk mengembangkan rasa nyata dalam kegiatan main. Selain itu, anak juga berkesempatan untuk meningkatkan kemampuan otak bagian kanan yang mungkin kurang terasah saat di rumah maupun di sekolah (Anggita, 2019).

\section{Permainan Tradisional sebagai Media} Sosialisasi

Anak belajar menempatkan diri sebagai makhluk sosial saat bermain dalam kelompok.
Saat berhasil masuk dalam suatu kelompok, anak akan merasa berhasil dalam mempelajari nilai keberhasilan pribadi. Ketika anak bermain peran "baik" maupun "jahat", ini akan menjadikan anak banyak memiliki pengalaman emosional, anak belajar memahami tentang rasa yang berkaitan dengan rasa takut serta penolakan dari suatu situasi yang dihadapi anak. Anak berkesempatan memprakrikkan rasa percayanya terhadap orang lain serta mampu bernegosiasi, problem solving atau sekedar bergaul dengan orang sekitar di dapat saat anak bermain (Anggita, 2019).

\section{Pengembangan Kreativitas}

Kemampuan dalam menciptakan sesuatu yang baru merupakan pengertian dari kreativitas itu sendiri, dan kreativitas perlu dikembangkan sejak usia dini. Kreativitas dapat berupa hasil produk maupun pemikiran/ide baru yang berguna sebagai sarana problem solving atau sebagai tolak ukur dalam melihat unsur yang telah ada sebelumnya. Pengembangan kreativitas anak usia dini dapat dilakukan, dikembangkan dan dirangsang melalui kegiatan permainan yang dilakukan anak di lingkungan sekitar dengan memanfaatkan sarana yang ada, alat permainan edukatif yang diberikan atau memanfaatkan sumber belajar yang ada (Istiana \& Simatupang, 2014).

Kreativitas dapat berkembang salah satunya melalui permainan tradisional. Pada permainan tradisional tidak hanya aspek motorik saja yang dikembangkan melainkan seluruh aspek perkembangan yaitu moral agama, bahasa, sosial emosional, kognitif, seni dan juga dapat mengembangkan kreativitas anak. Untuk mewujudkan permainan tradisional yang dapat mengembangkan kreativitas anak dibutuhkan seorang pendidik yang dapat memodifikasi permainan tradisional agar lebih bervariasi. Pemahaman yang dalam dari seorang pendidik mengenai karakteristik belajar anak merupakan faktor kunci dalam menyusun strategi pembelajaran yang menyenangkan, menarik serta bermakna bagi anak.

\section{Pentingnya Melestarikan Permainan} Tradisional Indonesia

Perlu diketahui bahwa Indonesia sangat kaya dengan berbagai warisan budaya, salah satunya adalah permainan tradisional. Permainan seperti engklek, egrang, gobak sodor, bentengan, petak umpet dan masih 
banyak lagi, itu merupakan jenis permainan yang menyenangkan jika dimainkan bersama teman-teman. Selain menyenangkan, permainan tradisional juga dapat mengembangkan kreativitas anak. Permainan tradisional dilaksanakan dengan berpedoman pada adat istiadat serta norma yang ada dalam masyarakat. Norma yang secara turun temurun diyakini dapat memberi perasaan tenang dan senang kepada para pemainnya. Secara umum permainan tradisional setiap wilayah di Nusantara mempunyai perbedaan serta kekhasan dari masing-masing daerah. Jika generasi muda tidak mengenal berbagai jenis permainan tradisional maka bisa jadi permainan tradisional ini akan hilang. Hal tersebut amat disayangkan jika sampai kita kehilangan permainan tradisional maka hilang pula kekayaan budaya bangsa. William Tedi (Anggita, 2019) menyatakan bahwa faktorfaktor yang menyebabkan permainan tradisional sudah mulai ditinggalkan antara lain: (a) tempat atau sarana tidak tersedia, (b) waktu yang terbatas, (c) terdesaknya permainan tradisional dengan permainan modern, (d) terputusnya pewarisan budaya.

Langkah yang dapat ditempuh sebagai usaha pelestarian permainan tradisional salah satunya adalah pendokumentasian kekayaan budaya demi mendapatkan satu gambaran informasi mengenai permainan tradisional agar dapat dikembangkan dan dihidupkan kembali serta menyampaikan secara efektif nilai moral yang terdapat pada permainan tradisional. Selain itu perlu upaya yang maksimal oleh pemerintah dan masyarakat dalam melestarikan permainan tradisional karena hasil kebudayaan dari permainan tradisional sangat kaya akan nilai luhur dan pesan moral. Jika tidak dimulai dari sekarang dengan segala usaha yang dilakukan, maka diperkirakan anak-anak generasi selanjutnya menjadi pribadi yang tidak memiliki identitas kebudayaan. Sudah saatnya orangtua untuk kembali mengajarkan aneka permainan tradisional kepada anak-anak karena disamping sebagai sarana mendidik, permainan tradisional lebih murah biayanya (Anggita, 2019).

Beberapa penelitian yang telah dilakukan mengenai manfaat serta pentingnya permainan tradisional membuktikan bahwa permainan tradisional bermanfaat dalam mengembangkan seluruh aspek perkembangan pada anak usia dini. Khalid Musyaddad (Musyaddad, 2019) melakukan penelitian dengan judul Permainan Tradisional sebagai Model Permainan Edukatif untuk Meningkatkan Kemampuan Sosial Emosional Anak Usia Dini, pada penelitian itu mengimplementasikan bahwa permainan tradisional dapat mengembangkan kemampuan anak dalam bersosialisasi atau menumbuhkan kecakapan sosial anak.

Terdapat juga penelitian dari Hasanah (Hasanah, 2016) dengan judul Permainan Tradisional Sebagai Media Stimulasi Aspek Perkembangan Anak Usia Dini. Dalam penelitian tersebut menunjukkan bahwa permainan tradisional dapat menjadi sarana atau media untuk menstimulasi aspek perkembangan anak, dalam hal ini aspek perkembangan kognitif, fisik motorik, sosial emosional, dan bahasa.

Penelitian lain yang dilakukan oleh Anggita (Anggita, 2019) yang berjudul Eksistensi Permainan Tradisional Sebagai Warisan Budaya Bangsa. Dapat diketahui bahwa permainan tradisional yang ada di Kabupaten Semarang jika dilihat dari keragaman serta jumlahnya tergolong masih banyak. Meski demikian, menurut penelitian ini kepopuleran permainan tradisional di Kabupaten Semarang terjadi penuruan dari sebelumnya. Oleh karenanya, dibutuhkan usaha serta perhatian khusus dari berbagai pihak pada permainan tradisional agar keberadaan permainan tradisional dapat terjaga dan dapat dipertahankan.

Dengan demikian semakin menguatkan bahwa permainan tradisional sangat bermanfaat untuk menstimulasi seluruh aspek perkembangan anak, di samping itu keberadaan permainan tradisional yang semakin sedikit ditemukan dimainkan oleh anak-anak membuat eksistensi permainan tradisional semakin turun dan menghilang. Untuk itu usaha melestarikan permainan tradisional dari berbagai pihak sangat dibutuhkan agar keberadaan permainan tradisional tetap dirasakan dan dimainkan bagi generasi mendatang. 


\section{SIMPULAN}

Permainan tradisional bukan hanya sebuah permainan yang membuat para pemainnya merasakan kesenangan tetapi dalam permainan tradisional juga membentuk karakter anak yang luhur serta mengambangkan seluruh aspek perkembangan anak. Dengan bermain, salah satunya dengan bermain permainan tradisional dapat memberi sumbangan positif pada anakanak antara lain berupa: membentuk tubuh yang bugar, sehat, dan tangguh; membentuk toleransi, demokratis, disiplin dan mental sportivitas; membentuk moral jujur, peka, tulus dan tanggap; membentuk kompetensi sosial berdaya saing, berkebangsaan, bekerjasama, dan bersahabat. Dengan permainan tradisional dapat membantu anakanak meningkatkan perkembangan seluruh aspek yang dimiliki secara terpadu dan menyeluruh untuk menjadi lebih cakap serta terampil. Terdapat garis pemisah antara kebudayaan asli dan kebudayaan dari luar yang masuk dalam era globalisasi seperti saat ini. Saat masyarakat menerima masuknya perubahan, maka perubahan sosial akan terjadi. Oleh karena itu, diperlukan kesadaran yang tertanam sejak dini agar kebudayaan lokal dapat terjaga dan tetap lestari. Jika tidak generasi ini yang menjaga kebudayaan maka, tidak menutup kemungkinan bahwa permainan tradisional akan memudar seiring berjalannya waktu.

\section{DAFTAR PUSTAKA}

Andriani, T. (2012). Permainan Tradisional Dalam Membentuk Karakter Anak Usia Dini. Jurnal Sosial Budaya, 9(1), 121-136.

Anggita, G. M. (2019). Eksistensi Permainan Tradisional sebagai Warisan Budaya Bangsa. JOSSAE: Journal of Sport Science and Education, $3(2), \quad 55$. https://doi.org/10.26740/jossae.v3n2.p55-59

Apriani, D. (2013). Penerapan Permainan Tradisional Engklek Untuk Meningkatkan Kemampuan Motorik Kasar Anak Kelompok B Ra Al Hidayah 2 Tarik Sidoarjo. PAUD Teratai, 2(1), 1-13.

Azizah, A. (2017). Studi kepustakaan mengenai landasan teori dan praktik konseling naratif. Jurnal BK UNESA, 7(2), 1-7.

Badu, R. W. (2011). Pengembangan Model Pelatihan Permainan Tradisional Edukatif
Berbasis Potensi Lokal Dalam Meningkatkan Pengetahuan Dan
Keterampilan Orang Tua Anak Usia Dini. Jiv, 6(2), 180-188. https://doi.org/10.21009/jiv.0602.8

Bakhtiar, A. M. (2018). Permainan Tradisional Egrang Untuk Melatih Keterampilan Kinestetik dan Sosial Anak. Jurnal JTIEE, 2(2), 76-84.

Ekayati, I. A. S. (2015). Pengaruh permainan tradisional "gobag sodor" terhadap kecerdasan intrapersonal dan interpersonal pada anak usia dini. Didaktika, 13(3), 1-10.

Erdiana, L. (2016). Pengaruh Permainan Tradisional Gobak Sodor terhadap Perkembangan Motorik Kasar dan Sikap Kooperatif Anak TK Kelompok B di Kecamatan Sidoarjo. Jurnal Pedagogi, 2(3), 9-17.

Hapidin1-Yenina2. (2016). Pengembangan Model Permainan Tradisional. Jurnal Pendidikan Usia Dini, 10(2), 201-212.

Hasanah, U. (2016). Pengembangan Kemampuan Fisik Motorik Melalui Permainan Tradisional Bagi Anak Usia Dini. Jurnal Pendidikan Anak, 5(1), 717-733. https://doi.org/10.21831/jpa.v5i1.12368

Istiana, L., \& Simatupang, N. (2014). Pengaruh Permainan Finger Painting Terhadap Kreativitas Anak Usia Dini Kelompok B Di Paud Melati. PAUD Teratai, 3(3), 1-6.

Iswantiningtyas, V., \& Wijaya, I. P. (2015). Meningkatkan Kemampuan Motorik Kasar Anak Usia Dini Melalui Permainan Tradisional Gobak Sodor. Jurnal PINUS, 1(3), 249-251.

Khusnul laely, D. yudi. (2015). Pengaruh permainan egrang tempurung kelapa terhadap peningkatan kecerdasan kinestetik anak. Empowerment, 3(2252), 32-41.

Mu'mala, Abad, K., \& Nadlifah. (2019). Optimalisasi Permainan Lompat Tali dalam Mengembangkan Motorik Kasar Anak Khuri Abad Mu'mala, Nadlifah | 57. Jurnal Ilmiah Tumbuh Kembang Anak Usia Dini, 4(1), 5768.

Munawaroh, H. (2018). Pengembangan Model Pembelajaran Dengan Modifikasi Permainan Congklak Sebagai Sarana Stimulasi Perkembangan Anak Usia Dini Di Ra Perwanida Wonosobo. Jurnal Penelitian Dan Pengabdian Kepada Masyarakat UNSIQ, 5(3), 302-313. https://doi.org/10.32699/ppkm.v5i3.477 
P ISSN 2548-6284 E ISSN 2615-0360

Vol. 5 No. 2 Juni 2021

Musyaddad, K. (2019). Permainan Tradisional Sebagai Model Permainan sosial dan interaksi anak satu dengan yang lainnya, bahkan lebih cenderung banyak. 2(1), 1424.

Niyati, M., \& Kurniah, N. (2016). Meningkatkan kecerdasan logika matematika melalui permainan congklak tradisional. Jurnal Ilmiah Potensia, 1(2), 78-83. https://ejournal.unib.ac.id/index.php/potensia /article/view/5676

Nugrahani, F. (2012). Dolanan jawa dalam rangka pembentukan karakter bangsa (kajian semiotik). Kajian Linguistik Dan Sastra, 24(1), 58-68.

Rahadian, A. (2020). Modul 4 Permainan Tradisional 1. 1-41.

SPD, A., \& Lailiyyah, L. (2018). Pengaruh Permainan Lompat Tali Terhadap Kemampuan Motorik Kasar Anak Kelompok B Tk Kartika Iv-9 Raider Surabaya. Wahana, 70(1), 63-70. https://doi.org/10.36456/wahana.v70i1.1570

Sudarto, S. (2018). Peningkatan keterampilan sosial melalui permainan gobak sodor. JPPM (Jurnal Pendidikan Dan Pemberdayaan Masyarakat), 5(1), 85-95. https://doi.org/10.21831/jppm.v5i1.10374

Trisnawaty, I. K. A. P. \& I. G. A. O. N. (2017). Pengaruh Permainan Tradisioal Engklek Terhadap Kemampuan Anak Dalam Mengenal Angka Pada Kelompok B Di Tk Bayu Kumdhala Bubunan. Jurnal Pendidikan Anak Usia Dini Undiksha, 5(1), 147-156.

https://ejournal.undiksha.ac.id/index.php/JJP AUD/article/view/11592 Data : 19-20-02

Widya, U., Mahakam, G., \& Playgroup, T. M. (2018). Melalui Permainan Tradisional Lompat Tali Pada Usia 5-6 Tahun Di Paud Tunas Mekar Plus Tahun Pelajaran 2017 / 2018. 55-69. 